\title{
Immune Cells Enhance Selectivity of Nanosecond-Pulsed DBD Plasma Against Tumor Cells
}

\author{
Abraham Lin, Billy Truong, Gregory Fridman, Alexander Fridman, \\ \& Vandana Miller* \\ Nyheim Drexel Plasma Institute, Drexel University, Philadelphia, PA \\ *Address all correspondence to: Vandana Miller, Nyheim Drexel Plasma Institute, Drexel University, 200 Federal Street, \\ Camden, NJ 08103; Tel.: 215.895.4074; Fax: 215.895.1633, E-mail: vmiller@coe.drexel.edu
}

\begin{abstract}
Cancer immunotherapy is a promising strategy that engages the patient's immune system to kill cancer cells selectively while sparing normal tissue. Treatment of macrophages with a nanosecond-pulsed dielectric barrier discharge directly enhanced their cytotoxic activity against tumor cells but not normal cells. These results underscore the clinical potential of plasma for cancer immunotherapy.
\end{abstract}

KEY WORDS: Nanosecond-Pulsed Plasma, Tumor Cells, Immune Cells, Selectivity, Macrophage, Immunotherapy

\section{INTRODUCTION}

Most of the chemotherapeutic agents and radiation used for treatment of cancers are not tumor specific and rely on their differential toxicity against tumor and noncancerous cells. ${ }^{1}$ Damage occurs to both cancerous and normal cells, but normal tissue is better able to repair cellular damage and recover. ${ }^{2,3}$ The usefulness of many of these treatments is compromised by the serious side effects that result from their use. ${ }^{4,5}$ Because they are administered systemically, they are distributed to tissues throughout the body and may produce damage to susceptible organs. ${ }^{1,4,6}$ In patients with incurable cancers in which palliation of symptoms is the goal, the severity of side effects may be worse than the disease itself., ${ }^{4-9}$ Therefore, the challenge of getting maximal therapeutic benefit while minimizing toxicity for anti-cancer therapies remains.

Non-equilibrium, atmospheric pressure plasma has been shown to exhibit comparable selectivity against tumor cells, so plasma development for cancer treatment has focused mainly on direct tumor cell killing both in vitro and in vivo. ${ }^{10-15}$ Ablative reduction of tumor masses has been demonstrated by most studies. The involvement of the immune system in the resolution of this disease with plasma has largely been ignored. ${ }^{5,16,17}$ For greatest clinical efficacy, plasma should attack cancerous cells selectively, preserve the integrity of surrounding normal tissue, and engage the body's natural innate and adaptive immunity against cancer. ${ }^{18}$ Because the immune system is designed to discriminate between self and non-self, ${ }^{19}$ tuning of plasma treatment to allow the immune system to retain this property could enhance the selectivity of both plasma and the immune system. The identification of non-self, danger signals is the function of antigen-presenting 
cells (APCs) such as macrophages and dendritic cells. ${ }^{19-22}$ Macrophages, originating from bone marrow progenitor cells, are key APCs. ${ }^{20,23}$ These progenitor cells develop into monocytes when released into the bloodstream and differentiate into tissue-specific macrophages displaying different phenotypes depending on the local environment. ${ }^{24,25}$ Activated pro-inflammatory macrophages secrete factors and cytotoxic substances such as tumor necrosis factor $\alpha$ (TNF- $\alpha$ ) and reactive oxygen and nitrogen species capable of killing cancerous cells. ${ }^{26-28}$ Secretion of these factors can activate macrophages to exert their direct anti-tumor effects. ${ }^{29-31}$

We have reported previously the enhancement of migration and anti-tumor function of macrophages in vitro by plasma (Table 1). ${ }^{32-35}$ In vivo effects of plasma treatment include differentiation of hemocytes in the lymph organs $48 \mathrm{~h}$ after plasma exposure of Drosophila melanogaster larvae, ${ }^{36}$ but the effect of plasma activated macrophages on normal cells has not been examined.

TABLE 1: Plasma has been reported to augment several macrophage functions

\begin{tabular}{lc}
\hline Macrophage function for which plasma has demonstrated effect & Reference(s) \\
1. Cytokine secretion & 34 \\
2. Migration to and from immune organs & 35 \\
3. Antigen presentation to T and B cells & $37-40$ \\
4. Cancer cell killing & $32,38,39$ \\
Macrophage function for which plasma effect has not been demonstrated & \\
5. Recognition of foreign antigens & 41,42 \\
6. Phagocytosis of foreign targets & 41,42 \\
7. Recruitment of other immune cells & 43 \\
\hline
\end{tabular}

In this study, we tested the hypothesis that the selectivity of plasma effects against cancer can be enhanced via direct engagement of immune cells. We treated human macrophages (differentiated THP-1 monocytes) with a nanosecond-pulsed dielectric barrier discharge (nspDBD) plasma. Bekeschus et al. treated THP-1 monocytes to study their redox modulation response to plasma. ${ }^{44}$ We co-cultured macrophages with human lung carcinoma cells (A549) or normal lung epithelial cells (Beas2B), unexposed to plasma, in semipermeable Transwell inserts (Fig. 1). This system separated the two cell types from direct contact but allowed for the exchange of soluble factors and signals in the medium. Cancer cell viability was quantified $48 \mathrm{~h}$ later to determine anti-tumor activity of macrophages.

Our results showed that plasma enhanced anti-tumor activity of macrophages through direct stimulation. While cancer cell viability decreased, normal cells remained unaffected. Therefore, further development of plasma to improve overall selectivity of treatment will provide a more efficacious and safe option for cancer immunotherapy. 




Plasma Treatment of Macrophages

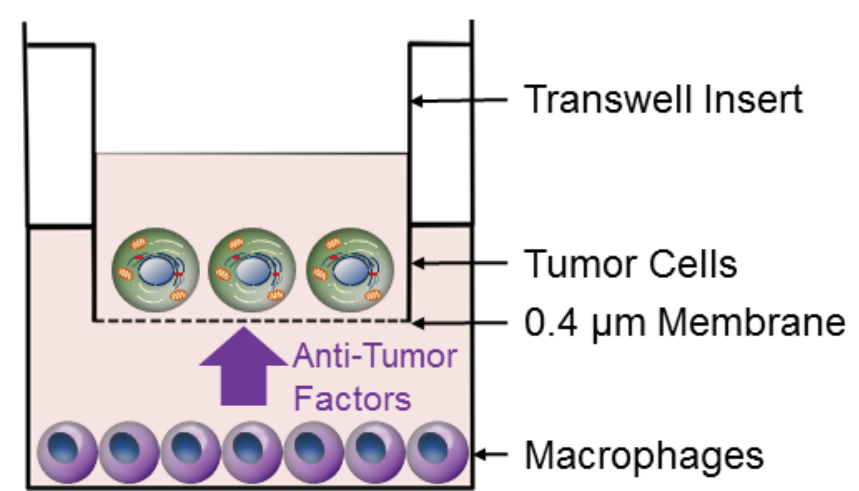

Co-Culture with Tumor Cells

FIG. 1: Transwell co-culture systems separated the macrophages and cancer cells from direct contact, but allowed for the exchange of soluble factors and signals through the medium. (A) Differentiated THP-1 monocytes (M0 macrophages) were exposed directly to plasma to stimulate the release of anti-tumor factors. Non-plasma-exposed A549 human lung carcinoma cells were cultured in the Transwell inserts having membranes with $0.4 \mu \mathrm{m}$ pores.

\section{MATERIALS AND METHODS}

\section{A. Cell Culture and Plating}

Human lung carcinoma cells (A549, ATCC: CCL-185) and normal human lung epithelial cells (Beas2B, ATCC: CRL-9609) were a gift from Dr. Bela Peethambaran (University of the Sciences, Philadelphia, PA). The human monocyte cell line (THP-1, ATCC:TIB-202) was a gift from Dr. Kara Spiller (Drexel University, Philadelphia, PA). All cells were cultured in RPMI 1640 with 10\% fetal bovine serum and $1 \%$ penicillin/streptomycin or RPMI 1640 with 10\% heat inactivated fetal bovine serum and $1 \%$ penicillin/streptomycin (Corning Life Sciences) and grown at $37^{\circ} \mathrm{C}$ with $5 \% \mathrm{CO}_{2}$ in a humidified atmosphere.

Cells were seeded at near confluency into 24 -well plates $(0.5 \mathrm{~mL} /$ well $) 1 \mathrm{~d}$ before plasma treatment. A549 cells were plated at $3.0 \times 10^{5}$ cells $/ \mathrm{mL}$, Beas2B cells were plated at $4.0 \times 10^{5}$ cells $/ \mathrm{mL}$, and THP- 1 cells were plated at $1.4 \times 10^{6}$ cells $/ \mathrm{mL}$. Before plasma treatment, cell culture media were emoved and cells were washed twice with phosphate-buffered saline (PBS). PBS from the second wash was removed right before plasma treatment and $0.5 \mathrm{~mL}$ of complete cell culture medium was added immediately after plasma exposure.

\section{B. Differentiation of THP-1 Monocytes to MO Macrophages}

THP-1 cells were differentiated into M0 macrophages $1 \mathrm{~d}$ before experiments by the addition of $0.5 \mu \mathrm{L}$ of $100 \mu \mathrm{L} / \mathrm{mL}$ phorbol 12-myristate 13-acetate (PMA) (Sigma-Aldrich) 
into the medium of each well in the 24-well plate or 24-well insert. Cells were incubated overnight and PBS was used to wash differentiated cells before plasma treatment and co-culture.

\section{NspDBD Plasma Treatment Parameters}

Cells were treated with nspDBD plasma as described in previous publications (Fig. 2). ${ }^{32,60}$ Briefly, we used a nanosecond pulser (FPB-20-05NM, FID GmbH) to produce 29 $\mathrm{kV}$ amplitude pulses and an external function generator (TTI, TG5011 LXT) to control pulse frequency. Each treatment was fixed at $10 \mathrm{sec}$ and plasma was applied $1 \mathrm{~mm}$ above the cells. The energy of each pulse, measured in our previous work, ${ }^{60}$ was $0.9 \mathrm{~mJ} / \mathrm{pulse}$. Together with frequency and treatment time, the total plasma energy delivered to the cell was calculated. Plasma treatment parameters are listed in Table 2.

\section{Cell Viability Assay}

Cell viability was assessed with a propidium iodide (PI) (Thermo Fisher Scientific) exclusion assay. Damaged cell membranes allow for PI, a fluorescent agent, to penetrate
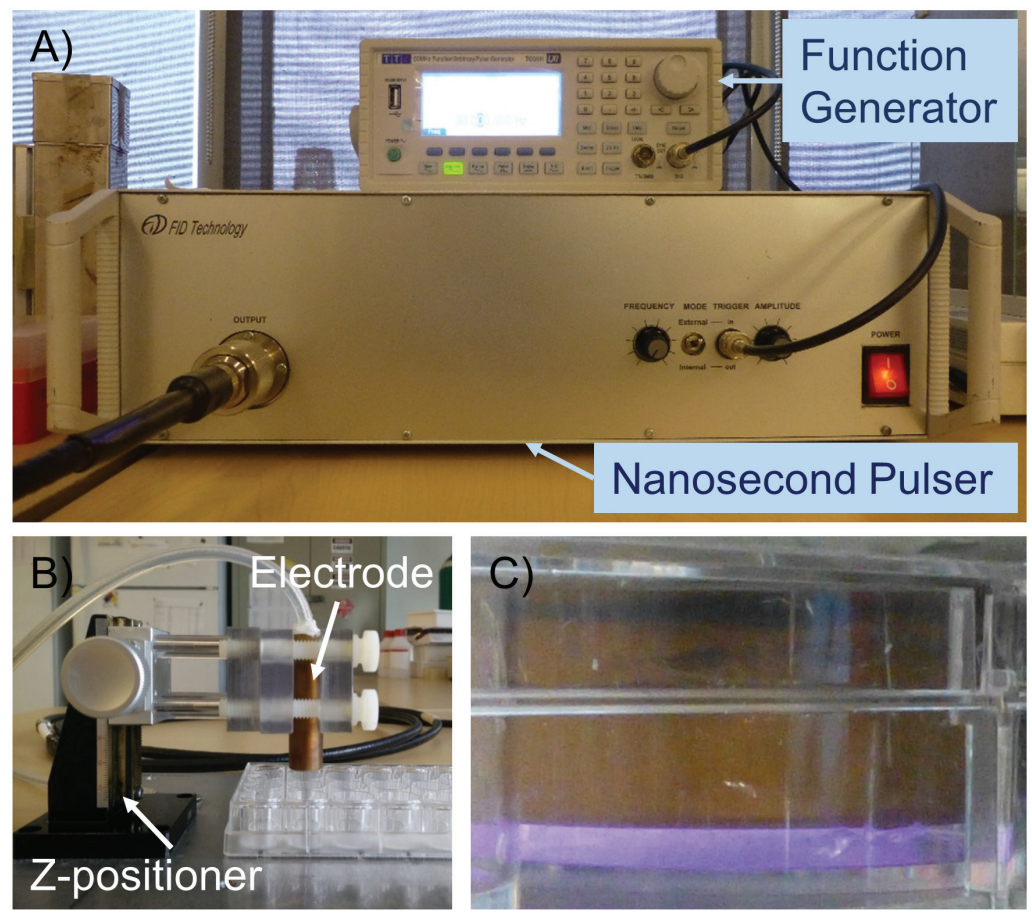

FIG. 2: NspDBD plasma treatment system. (A) High-voltage pulses are delivered by a nanosecond pulser and with a function generator. (B) A z-positioner was use to position the electrode above the cells in the 24-well plate. (C) Plasma is generated in direct contact with cells. 
TABLE 2: nspDBD plasma treatment parameters

\begin{tabular}{ll}
\hline Parameter & Value \\
\hline Excitation & Nanosecond pulsed \\
Regime & Uniform \\
Voltage & $29 \mathrm{kV}$ \\
Rise time & $2 \mathrm{~ns}$ \\
Pulse width & $20 \mathrm{~ns}$ \\
Gap distance & $1 \mathrm{~mm}$ \\
Energy per pulse & $0.9 \mathrm{~mJ} /$ pulse \\
Frequency & $5,15,30,75 \mathrm{~Hz}$ \\
Treatment time & $10 \mathrm{sec}$ \\
Plasma treatment energies & $50,100,300,700 \mathrm{~mJ}$ \\
\hline
\end{tabular}

into the cell and bind to DNA. One hour after plasma treatment, cells were detached with either $0.25 \%$ trypsin/ $0.1 \%$ EDTA in HBSS (Corning) or 5 mM EDTA in PBS (EMD Millipore) and stained with $100 \mu \mathrm{L} / \mathrm{mL}$ PI (Invitrogen). For co-culturing experiments, cells were collected and stained at $48 \mathrm{~h}$ after plasma and co-culture. An image cytometer (Nexcelom CBA Vision, Nexcelom Bioscience) was used to quantify live cells. FCS flow cytometry software (FCS 4.0, DeNovo Software) was used to perform size gating. To determine viability, live cell counts for each treatment group was normalized to the average live cell counts of the untreated controls and data are represented as a percentage of controls.

\section{E. Plasma-Treated Macrophages with Cancerous and Normal Cells}

THP-1 M0 macrophages were exposed to plasma and co-cultured with either A549 or Beas2B cells. THP-1 monocytes were seeded into 24-well plates and differentiated into M0 macrophages with $0.5 \mu \mathrm{L}$ of PMA $(100 \mu \mathrm{L} / \mathrm{mL}) 1 \mathrm{~d}$ before to plasma treatment. A549 and Beas2B cells were seeded separately into Transwell inserts (Corning Life Sciences) at $0.3 \times 10^{5}$ cells/insert with $600 \mu \mathrm{L}$ in the basal layer.

Cells were washed twice immediately before plasma treatment of M0 macrophages and $750 \mu \mathrm{L}$ of complete THP-1 medium was added immediately after. Inserts with either A549 cells or Beas2B cells were placed into the plasma-treated wells and $750 \mu \mathrm{L}$ of corresponding complete medium was added. Media were changed the next day and cells remained in culture for an additional $24 \mathrm{~h}$ before viability analysis.

\section{F. Statistical Analysis}

Experiments were performed with a minimum of three replicates and repeated at least twice. Data are presented as mean \pm SEM. One-way ANOVA with post hoc Dunnett's 
or Tukey's multiple-comparisons test and two-way ANOVA test with post hoc Sidak's multiple-comparisons test were performed in GraphPad Prism 6. $p<0.05$ was considered significant.

\section{RESULTS}

\section{A. Cancer Cells (A549) are More Sensitive to Plasma than Immune Cells (THP-1) and Non-Cancerous Cells (Beas2B)}

Cancer cells, normal tissue, and immune cells such as dendritic cells and macrophages are all present in the tumor microenvironment ${ }^{45}$ and will be exposed to plasma during treatment of tumors. Therefore, plasma regimes should be developed to deliver maximum cytotoxicity to cancerous cells with minimal damage to other cells. In this study, we used a lung carcinoma cell line (A549), a normal lung epithelial cell line (Beas2B), and PMAdifferentiated THP-1 macrophages (M0 macrophages) to represent the three cell types. We compared their susceptibility to plasma by measuring cell viability $1 \mathrm{~h}$ after treatment. Cells seeded into 24-well plates $1 \mathrm{~d}$ before treatment were exposed to nspDBD plasma at $29 \mathrm{kV}$ for $10 \mathrm{sec}$. Frequency of pulses was adjusted to deliver a range of plasma energies.

After plasma exposure, viable cells were quantified with a PI exclusion assay. We observed that plasma had an energy-dependent effect on cell viability; at low treatment energy $(50 \mathrm{~mJ})$, there was minimal effect on cell viability for all three cell types (Fig. 3). At higher energies, loss of viable A549 cells was greater than that of both normal lung epithelial cells and macrophages. This is consistent with previous reports and may be partially attributed to the different intracellular redox environments between normal and cancerous cells. ${ }^{46-48}$ Based on these results, we selected 100 and $300 \mathrm{~mJ}$ treatment for the subsequent experiment.

\section{B. Plasma Directly Enhanced Anti-Tumor Activity of Macrophages}

To investigate whether plasma can stimulate the anti-tumor activity of macrophages directly, we co-cultured plasma-treated M0 macrophages with A549 cells in a Transwell system for $48 \mathrm{~h}$ (Fig. 1). A549 viability after co-culture with macrophages not exposed to plasma was $58 \%$. This served as our control for the baseline anti-tumor activity of macrophages in co-culture (represented in the figures as $0 \mathrm{~mJ}$ ). Both $100 \mathrm{~mJ}$ and $300 \mathrm{~mJ}$ plasma treatment of macrophages reduced A549 viability to less than $43 \%$ (Fig. 4). Co-culture of plasma-treated macrophages with the normal Beas2B epithelial cells did not affect their viability. Taken together, these results strongly indicate that plasma can enhance cytotoxic activity of macrophages directly and selectively against cancerous cells.

\section{DISCUSSION}

Conventional treatments, such as chemotherapeutics and radiation, are only partially tumor specific and destroy cancer cells in the body, often at the expense of significant 


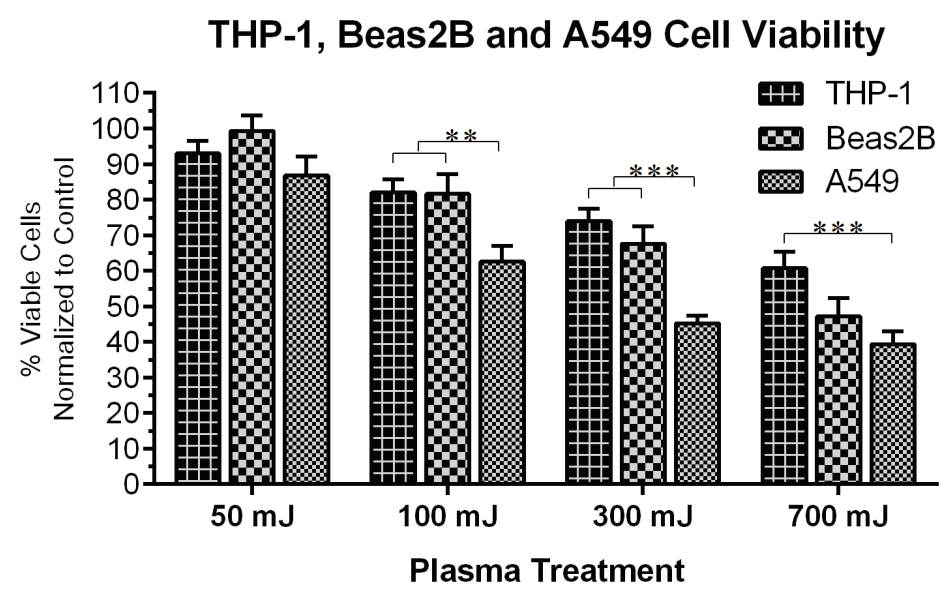

FIG. 3: A549 lung carcinoma cells are more sensitive to plasma treatment compared with immune cells (THP-1) and normal lung epithelial cells (Beas2B). Cells were seeded into 24-well plates $1 \mathrm{~d}$ before plasma treatment. A PI exclusion assay was performed $1 \mathrm{~h}$ after plasma treatment and cell viability was determined by normalizing live cell counts to untreated controls. Data are shown as mean \pm SEM. ${ }^{*} p<0.05,{ }^{* *} p<0.05, * * * p<0.001$ (two-way ANOVA, Dunnett's multiple-comparisons test).

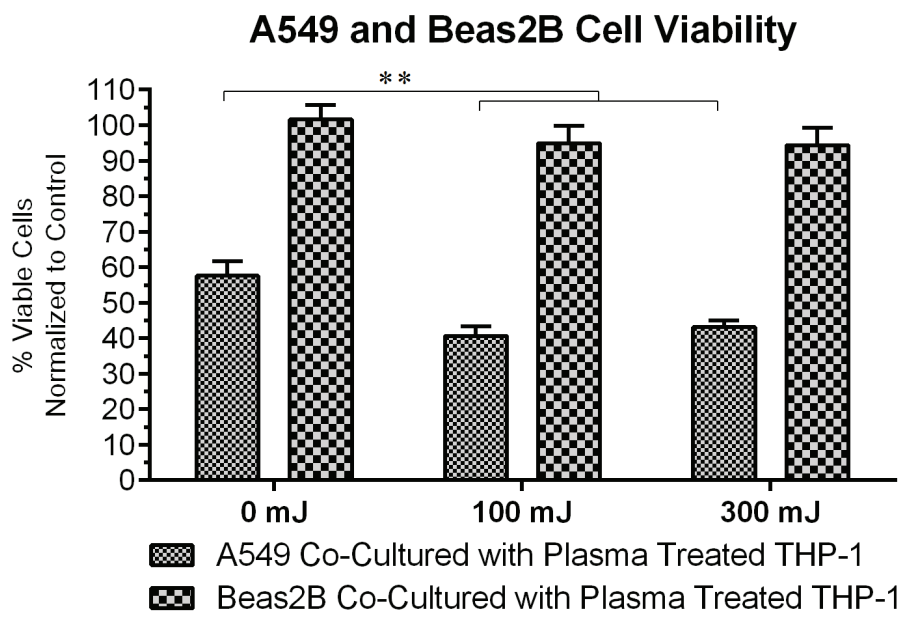

FIG. 4: Plasma-enhanced anti-tumor activity of M0 macrophages. To determine whether plasma stimulated macrophages could kill cancerous cells selectively, macrophages were exposed to plasma and co-cultured with either A549 cancer cells or normal Beas2B lung epithelial cells. After $48 \mathrm{~h}$ of co-culture, both A549 and Beas2B cells were collected and viability was determined with a PI exclusion assay. Neither A549 nor Beas2B cells came in direct contact with plasma. Therefore, any observed killing effects are a result of secreted factors from macrophages. Data are shown as mean \pm SEM. ${ }^{*} p<0.05,{ }^{* *} p<0.05,{ }^{* * *} p<0.001$ (one-way ANOVA, Dunnett's multiple-comparisons test). 
toxicity to normal tissue..$^{2,4,6}$ In contrast, immunotherapy is focused on activating the body's natural defenses to target tumors selectively for therapeutic benefit against cancer. ${ }^{1,16}$ This ensures that only cancer cells are destroyed by activated immune cells and that the host's normal cells remain healthy.

Most recent advancements in plasma treatment of tumors have focused on optimization of ablative regimes and reduction of bystander effects on normal cells. ${ }^{13,49,50}$ By varying the energy deposited on target tissues, plasma regimes toxic to tumor cells and relatively safe for normal cells were identified for use. This may be done by varying treatment time, distance from source, carrier gases, voltage, and frequency. However, in animal models of cancer treated at these regimes, successful reduction in tumor volumes and increased mean survival were associated with damage to surrounding normal tissue and tumor recurrence when treatment was discontinued. ${ }^{13,49,50}$ We propose that moving away from ablative regimes of plasma for treatment into regimes that promote stimulation of immune-mediated tumor cell killing may improve clinical outcomes and reduce damaging effects to neighboring tissue. Direct enhancement of immune cell function by plasma is an advantage of plasma for cancer immunotherapy.

Plasma treatment of multiple human cell lines with our nspDBD system demonstrated that cancerous cells are more sensitive to plasma compared with their normal counterparts even at lower energies (Fig. 3). This further supports that plasma can be safely applied to induce cell death in cancerous cells while minimizing damage to surrounding normal tissue.

When macrophages were stimulated directly with plasma, they were more effective at killing A549 cells (Fig. 4). The killing activity of plasma-activated macrophages is, at least in part, due to the release of TNF- $\alpha,{ }^{34}$ a proinflammatory cytokine known to be cytotoxic to cancerous cells. ${ }^{51,52}$ Kaushik, et al. reported that macrophages treated with plasma released TNF- $\alpha$, which reduced viability of A549 cells in co-culture. This effect was reversed by lenalidomide, a TNF- $\alpha$-specific inhibitor. ${ }^{34}$

There was no effect of plasma-activated macrophages on the normal lung epithelial cell line, suggesting that macrophages maintain their selectivity to kill cancerous cells when stimulated with plasma. The different outcomes on normal and cancer cells may be attributed in part to their response to the released cytokines. TNF- $\alpha$ is strongly cytotoxic toward tumor cells but induces interleukin 6 (IL-6) and IL-8 secretion from Beas2B cells, the normal cells. ${ }^{53,54}$ Both of these cytokines enhance cell survival and proliferation of normal epithelial/endothelial cell lines. ${ }^{55-58}$ This suggests that plasma-mediated cancer therapy may be applied safely for direct augmentation of immune cell function while preserving selectivity (Fig. 5). This is a significant advantage over radiation because APCs are among the most radiosensitive cells in the body. ${ }^{59}$ These effects are also observed in treatment of live whole organisms. Lee et al. reported that a single $10 \mathrm{sec}$ treatment of Drosophila larvae increased the numbers of fully differentiated hemocytes in the lymph organ within 48 h. ${ }^{36}$ Development of these larvae was followed and they achieved physiological and developmental milestones similar to untreated larvae. This further supports the safety of plasma for development of future clinical applications. 


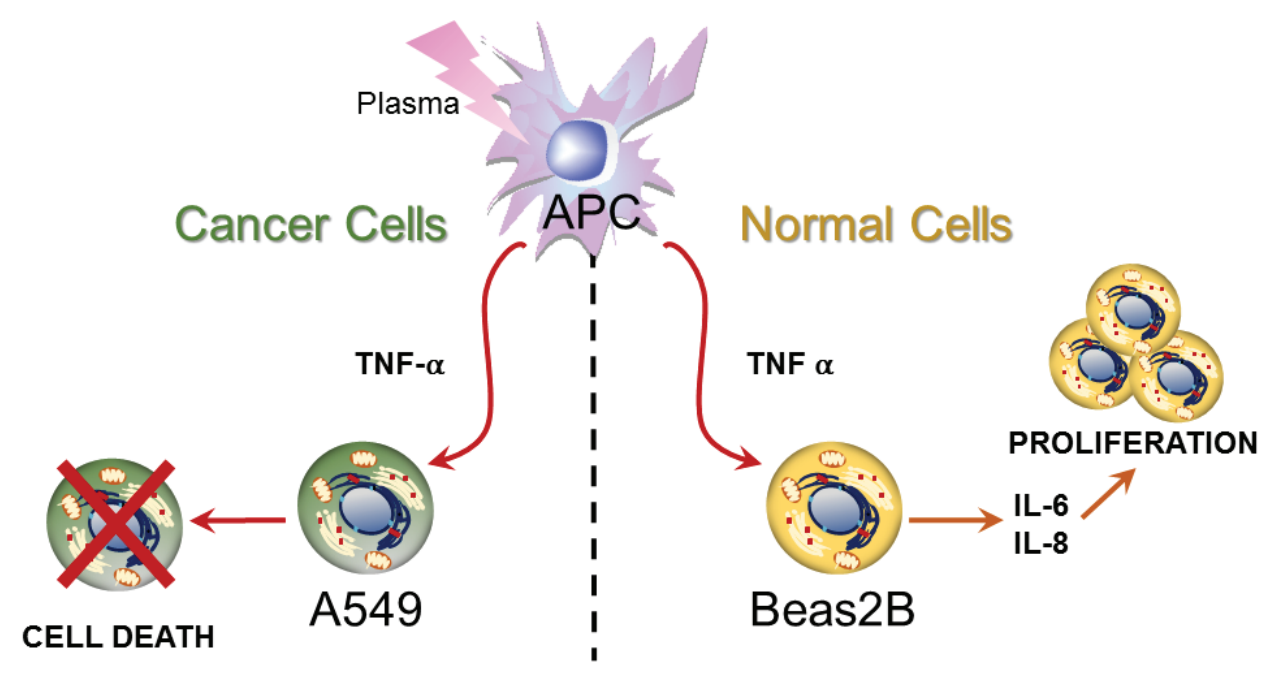

FIG. 5: Plasma-stimulated macrophages exhibit selective killing of cancerous cells.

\section{CONCLUSION}

This study provides evidence that non-thermal plasma has two major advantages over current treatment modalities: (1) greater selectivity towards cancer cells and (2) enhancement of anti-tumor activity of macrophages. Therefore, plasma has the potential to be an efficacious and safe cancer therapeutic option via engagement of the immune system.

\section{REFERENCES}

1. Palumbo MO, Kavan P, Miller WH Jr, Panasci L, Assouline S, Johnson N, Cohen V, Patenaude F, Pollak M, Jagoe RT. Systemic cancer therapy: achievements and challenges that lie ahead. Front Pharmacol. 2013;4:57.

2. Bentzen SM. Preventing or reducing late side effects of radiation therapy: radiobiology meets molecular pathology. Nat Rev Cancer. 2006;6(9):702-13.

3. Yasuda H. Solid tumor physiology and hypoxia-induced chemo/radio-resistance: novel strategy for cancer therapy: nitric oxide donor as a therapeutic enhancer. Nitric Oxide. 2008;19(2):205-16.

4. Sun CC, Bodurka DC, Weaver CB, Rasu R, Wolf JK, Bevers MW, Smith JA, Wharton JT, Rubenstein EB. Rankings and symptom assessments of side effects from chemotherapy: insights from experienced patients with ovarian cancer. Support Care Cancer. 2005;13(4):219-27.

5. Zitvogel L, Apetoh L, Ghiringhelli F, Kroemer G. Immunological aspects of cancer chemotherapy. Nat Rev Immunol. 2008;8(1):59-73.

6. Burstein HJ. Side effects of chemotherapy. Case 1. Radiation recall dermatitis from gemcitabine. J Clin Oncol. 2000;18(3):693-4.

7. Ahles TA, Saykin AJ, Furstenberg CT, Cole B, Mott LA, Skalla K, Whedon MB, Bivens S, Mitchell T, Greenberg ER. Neuropsychologic impact of standard-dose systemic chemotherapy in long-term survivors of breast cancer and lymphoma. J Clin Oncol. 2002;20(2):485-93.

8. Peeters K, Van De Velde C, Leer J, Martijn H, Junggeburt J, Kranenbarg EK, Steup W, Wiggers T, 
Rutten H, Marijnen C. Late side effects of short-course preoperative radiotherapy combined with total mesorectal excision for rectal cancer: increased bowel dysfunction in irradiated patients: a Dutch colorectal cancer group study. J Clin Oncol. 2005;23(25):6199-206.

9. Gupta K, Miller JD, Li JZ, Russell MW, Charbonneau C. Epidemiologic and socioeconomic burden of metastatic renal cell carcinoma (mRCC): a literature review. Cancer Treat Rev. 2008;34(3):193-205.

10. Keidar M, Walk R, Shashurin A, Srinivasan P, Sandler A, Dasgupta S, Ravi R, Guerrero-Preston R, Trink B. Cold plasma selectivity and the possibility of a paradigm shift in cancer therapy. Br J Cancer. 2011;105(9):1295-301.

11. Keidar M, Shashurin A, Volotskova O, Stepp MA, Srinivasan P, Sandler A, Trink B. Cold atmospheric plasma in cancer therapy. Phys Plasmas. 2013;20(5):057101.

12. Schlegel J, Köritzer J, Boxhammer V. Plasma in cancer treatment. Clin Plasma Med. 2013;1(2):2-7.

13. Vandamme M, Robert E, Pesnel S, Barbosa E, Dozias S, Sobilo J, Lerondel S, Le Pape A, Pouvesle JM. Antitumor effect of plasma treatment on U87 glioma xenografts: preliminary results. Plasma Process Polym. 2010;7(3-4):264-73.

14. Vandamme M, Robert E, Lerondel S, Sarron V, Ries D, Dozias S, Sobilo J, Gosset D, Kieda C, Legrain B. ROS implication in a new antitumor strategy based on non-thermal plasma. Int J Cancer. 2012;130(9):2185-94.

15. Hirst AM, Frame FM, Arya M, Maitland NJ, O’Connell D. Low temperature plasmas as emerging cancer therapeutics: the state of play and thoughts for the future. Tumour Biol. 2016;37:7021-31.

16. Mellman I, Coukos G, Dranoff G. Cancer immunotherapy comes of age. Nature. 2011;480(7378):480-9.

17. Metelmann H-R, Nedrelow DS, Seebauer C, Schuster M, von Woedtke T, Weltmann K-D, Kindler S, Metelmann PH, Finkelstein SE, Von Hoff DD. Head and neck cancer treatment and physical plasma. Clin Plasma Med. 2015;3(1):17-23.

18. Haynes NM, van der Most RG, Lake RA, Smyth MJ. Immunogenic anti-cancer chemotherapy as an emerging concept. Curr Opin Immunol. 2008;20(5):545-57.

19. Pardoll D. Does the immune system see tumors as foreign or self? Annu Rev Immunol. 2003;21: 807-39.

20. Unanue ER. Antigen-presenting function of the macrophage. Annu Rev Immunol. 1984;2(1):395-428.

21. Guermonprez P, Valladeau J, Zitvogel L, Théry C, Amigorena S. Antigen presentation and T cell stimulation by dendritic cells. Annu Rev Immunol. 2002;20(1):621-67.

22. Savina A, Amigorena S. Phagocytosis and antigen presentation in dendritic cells. Immunol Rev. 2007;219(1):143-56.

23. Biswas SK, Mantovani A. Macrophage plasticity and interaction with lymphocyte subsets: cancer as a paradigm. Nat Immunol. 2010;11(10):889-96.

24. Bingle L, Brown N, Lewis C. The role of tumour-associated macrophages in tumour progression: implications for new anticancer therapies. J Pathol. 2002;196(3):254-65.

25. Lewis CE, Pollard JW. Distinct role of macrophages in different tumor microenvironments. Cancer Res. 2006;66(2):605-12.

26. Iles KE, Forman HJ. Macrophage signaling and respiratory burst. Immunol Res. 2002;26(1-3):95-105.

27. Dupré-Crochet S, Erard M, Nüße O. ROS production in phagocytes: why, when, and where? J Leukoc Biol. 2013;94(4):657-70.

28. Spiller KL, Anfang RR, Spiller KJ, Ng J, Nakazawa KR, Daulton JW, Vunjak-Novakovic G. The role of macrophage phenotype in vascularization of tissue engineering scaffolds. Biomaterials. 2014;35(15):4477-88.

29. Engström A, Erlandsson A, Delbro D, Wijkander J. Conditioned media from macrophages of M1, but not M2 phenotype, inhibit the proliferation of the colon cancer cell lines HT-29 and CACO-2. Int J Oncol. 2014;44(2):385-92.

30. Hedbrant A, Erlandsson A, Delbro D, Wijkander J. Conditioned media from human macrophages of M1 phenotype attenuate the cytotoxic effect of 5-fluorouracil on the HT-29 colon cancer cell line. Int J Oncol. 2015;46(1):37-46. 
31. Hicks AM, Willingham MC, Du W, Pang CS, Old LJ, Cui Z. Effector mechanisms of the anti-cancer immune responses of macrophages in SR/CR mice. Cancer Immun. 2006;6(1):11.

32. Lin A, Truong B, Pappas A, Kirifides L, Oubarri A, Chen S, Lin S, Dobrynin D, Fridman G, Fridman A. Uniform nanosecond pulsed dielectric barrier discharge plasma enhances anti-tumor effects by induction of immunogenic cell death in tumors and stimulation of macrophages. Plasma Process Polym. 2015;12(12):1392-9.

33. Miller V, Lin A, Fridman A. Why target immune cells for plasma treatment of cancer. Plasma Chem Plasma Process. 2016;36:259-68.

34. Kaushik NK, Kaushik N, Min B, Choi KH, Hong YJ, Miller V, Fridman A, Choi EH. Cytotoxic macrophage-released tumour necrosis factor-alpha (TNF- $\alpha$ ) as a killing mechanism for cancer cell death after cold plasma activation. J Phys D: Appl Phys. 2016;49(8):084001.

35. Miller V, Lin A, Fridman G, Dobrynin D, Fridman A. Plasma stimulation of migration of macrophages. Plasma Process Polym. 2014;11(12):1193-7.

36. Lee A, Lin A, Shah K, Singh H, Miller V, Rao SG. Optimization of non-thermal plasma treatment in an in vivo model organism. PLoS One. 2016;11(8):e0160676.

37. Miller V, Lin A, Fridman A. Plasma activation of the immune system: new approach for treating cancers. 22nd International Symposium on Plasma Chemistry, July 6, 2015, Antwerp, Belgium, 2015.

38. Lin A, Xiang B, Anastasi A, Dobrynin D, Fridman G, Fridman A, Snook A, Miller V. Nanosecond pulsed DBD for plasma onco-immunotherapy. 22nd International Symposium on Plasma Chemistry, July 6, 2015, Antwerp, Belgium, 2015.

39. Lin A, Xiang B, Ranieri P, Snook A, Fridman G, Fridman A, Miller V. Non-thermal plasma application for cancer immunotherapy. 3rd International Workshop on Plasma for Cancer Treatment, Washington DC, 2016.

40. Lin A, Xiang B, Snook A, Fridman G, Fridman A, Miller V. Non-thermal plasma induction of immunogenic cell death in an in vivo tumor mouse model. 6th Internation Conference on Plasma Medicine, Bratislava, Slovakia, 2016.

41. Jaiswal S, Chao MP, Majeti R, Weissman IL. Macrophages as mediators of tumor immunosurveillance. Trends Immunol. 2010;31(6):212-9.

42. Janeway CA Jr, Medzhitov R. Innate immune recognition. Annu Rev Immunol. 2002;20(1):197-216.

43. Mantovani A, Sica A. Macrophages, innate immunity and cancer: balance, tolerance, and diversity. Curr Opin Immunol. 2010;22(2):231-7.

44. Bekeschus S, Schmidt A, Bethge L, Masur K, von Woedtke T, Hasse S, Wende K. Redox stimulation of human thp-1 monocytes in response to cold physical plasma. Oxid Med Cell Longev. 2016;2016:5910695.

45. Gajewski TF, Schreiber H, Fu Y-X. Innate and adaptive immune cells in the tumor microenvironment. Nat Immunol. 2013;14(10):1014-22.

46. Volotskova O, Hawley TS, Stepp MA, Keidar M. Targeting the cancer cell cycle by cold atmospheric plasma. Sci Rep. 2012;2:636.

47. Zucker SN, Zirnheld J, Bagati A, DiSanto TM, Des Soye B, Wawrzyniak JA, Etemadi K, Nikiforov M, Berezney R. Preferential induction of apoptotic cell death in melanoma cells as compared with normal keratinocytes using a non-thermal plasma torch. Cancer Biol Ther. 2012;13(13):1299-306.

48. Panngom K, Baik KY, Ryu YH, Uhm HS, Choi EH. Differential responses of cancer cell lines to nonthermal plasma from dielectric barrier discharge. Curr Appl Physics. 2013;13:S6-S11.

49. Walk RM, Snyder JA, Srinivasan P, Kirsch J, Diaz SO, Blanco FC, Shashurin A, Keidar M, Sandler AD. Cold atmospheric plasma for the ablative treatment of neuroblastoma. J Pediatr Surg. 2013;48(1):67-73.

50. Chernets N, Kurpad DS, Alexeev V, Rodrigues DB, Freeman TA. Reaction chemistry generated by nanosecond pulsed dielectric barrier discharge treatment is responsible for the tumor eradication in the B16 melanoma mouse model. Plasma Process Polym. 2015.

51. Anderson GM, Nakada MT, DeWitte M. Tumor necrosis factor- $\alpha$ in the pathogenesis and treatment of cancer. Curr Opin Pharmacol. 2004;4(4):314-20. 
52. Carswell E, Old LJ, Kassel R, Green S, Fiore N, Williamson B. An endotoxin-induced serum factor that causes necrosis of tumors. Proc Natl Acad Sci U S A. 1975;72(9):3666-70.

53. Cromwell O, Hamid Q, Corrigan C, Barkans J, Meng Q, Collins P, Kay A. Expression and generation of interleukin-8, IL-6 and granulocyte-macrophage colony-stimulating factor by bronchial epithelial cells and enhancement by IL-1 beta and tumour necrosis factor-alpha. Immunology. 1992;77(3):330.

54. Steerenberg P, Zonnenberg J, Dormans J, Joon P, Wouters I, Van Bree L, Scheepers P, Van Loveren H. Diesel exhaust particles induced release of interleukin 6 and 8 by (primed) human bronchial epithelial cells (BEAS 2B) in vitro. Exp Lung Res. 1998;24:85-100.

55. Li A, Dubey S, Varney ML, Dave BJ, Singh RK. IL-8 directly enhanced endothelial cell survival, proliferation, and matrix metalloproteinases production and regulated angiogenesis. J Immunol. 2003;170(6):3369-76.

56. Koch AE, Polverini PJ, Kunkel SL, Harlow LA, DiPietro LA, Elner VM, Elner SG, Strieter RM. Interleukin-8 as a macrophage-derived mediator of angiogenesis. Science. 1992;258:1798-801.

57. Tuschil A, Lam C, Haslberger A, Lindley I. Interleukin-8 stimulates calcium transients and promotes epidermal cell proliferation. J Investig Dermatol.1992;99(3):294-8.

58. Ray S, Ju X, Sun H, Finnerty CC, Herndon DN, Brasier AR. The IL-6 trans-signaling-STAT3 pathway mediates ECM and cellular proliferation in fibroblasts from hypertrophic scar. J Investig Dermatol. 2013;133(5):1212-20.

59. Manda K, Glasow A, Paape D, Hildebrandt G. Effects of ionizing radiation on the immune system with special emphasis on the interaction of dendritic and T cells. Front Oncol. 2012;2:102.

60. Lin A, Chernets N, Han J, Alicea Y, Dobrynin D, Fridman G, Freeman TA, Fridman A, Miller V. Nonequilibrium dielectric barrier discharge treatment of mesenchymal stem cells: charges and reactive oxygen species play the major role in cell death. Plasma Process Polym. 2015;12(10):111-27. 